\title{
Standardization of Data Management and Treatment for Scanning Probe Microscopy Daisuke FUJITA*1
}

${ }^{* 1}$ Advanced Key Technologies Division, National Institute for Materials Science 1-2-1 Sengen, Tsukuba-shi, Ibaraki 305-0047, Japan

(Received January 6, 2013, Accepted April 11, 2013)

Recent standardization activities on data treatment and management for scanning probe microscopy (SPM), performed in ISO TC 201, are reviewed. International Standard ISO 28600 on standard data transfer format for SPM is introduced. The data conversion software compatible with ISO 28600 will facilitate inter-exchangeability and consistent treatment of data, enhance productivity of data-processing programs, and increase accuracy and quantification. Once the data format has been standardized, the focus should shift to standardizing data-processing procedures such as drift correction, probe-tip characterization, and image restoration. To make SPMs reliable tools for nanometrology, standardization of quantitative image restoration is necessary. A solution relying on mathematical morphology is introduced to reduce artifacts caused by probe shape. The use of well-characterized probes with known probe shapes is critical to accurate reconstruction of topography images. Our final goal is establishment of a comprehensive SPM database integrated with a common data-processing environment.

\section{1. はじめに一SPM の発展と標準化一}

IBM チューリッヒ研究所の Binnig と Rohrer らが1981年 に走査型トンネル顕微鏡（Scanning Tunneling Microscopy, STM）を発明して以来 ${ }^{1)}$, 表面構造や機能物性を実空間か つナノスケールで計測・画像化できる表面敏感な顕微鏡法と して, 走査型プローブ顕微鏡法 ( Scanning Probe Microscopy, SPM) は飛躍的に発展してきた. STMの発明 者である Binnig とRohrer は1986年に「走査型トンネル電 子顕微鏡の設計」の功績によりノーベル物理学賞を受賞し た. 一方, Binnig らのSTMの発明に先立つ先駆的な研究 開発は1960年代後半から米国の国立標準技術研究所 (National Institute for Standards and Technology, NIST) の Young らにより開始されていた. Young らは1971年に表 面一探針間電流を用いることにより表面の形状測定が可能で あることをトポグラファイナ（Topografiner）と呼ばれる装 置により実証した ${ }^{2)}$. Young らの開発したトポグラファイナ は，原子分解能が実現できなかったことを除けば，STMの 構成用件を備えた画期的な計測装置であった。

STM は導電性試料が対象であったが，1986年には絶縁体 にも適用可能な顕微鏡として Binnig, Quate, Gerberによ って原子間力顕微鏡 (Atomic Force Microscopy, AFM) が 発明された ${ }^{3)}$. その後, STM やAFM をべースとして多様 な SPM が開発され, 表面物性や機能の多元的ナノ計測が実 現された. SPM は測定へッドが比較的コンパクトであり, 適合性に優れ, 超高真空のみならず大気中や液中, 極低温, 高温, 応力場, 光照射場などの多様な環境場で使用でき る4). また，探針一表面近接相互作用を利用し，ナノ創製や 微細加工などのナノテクッールとしても応用される5).

標準化は計測法が汎用性を有し, 世界的市場が形成される

*1 独物質 · 材料研究機構先端的共通技術部門（下305-0047 茨城 県つくば市千現 1-2-1)
とともに必要性が認識され, 標準化のための研究（pre-standardization research）が開始される.このプレ標準化研究 のプラットフォーム的役割を担う国際的スキームがベルサイ ユサミット合意により1980年代に設置された先進材料と標 準に関するベルサイユプロジェクトVAMAS（Versailles Project on Advanced Materials and Standards) である. VAMAS は, 特に表面化学分析のプレ標準化研究において 数多くの先駆的な成果を挙げている ${ }^{6)}$. 国際標準の制定前段 階における国際的な機関間試験であるラウンドロビンテスト (Round-Robin Test, RRT) を実施するスキームとしての貢 献も大きい.

一方，米国ではASTM-E42 委員会（surface analysis） に颃いて1990年代から SPM のプレ標準化的なガイドライン が策定された ${ }^{7)}$. 並行して計量標準の立場から AFM を寸法 測定法として位置づける目的で1990年代後半から各国の国 立標準研究所を中心として国際共同研究が開始されている ${ }^{8)}$.

様々なスキームでのプレ標準化研究の実績に基づきつつ, 参加国の対等な審議に基づいて工業分野の国際標準（International Standard）を制定する組織が国際標準化機構（International Organization for Standardization, ISO) である. ISO におけるSPM の標準化は TC 201（表面化学分析）に おいて行われ, 所掌するSub-Committee として SC 9 が 2004年に設置された ${ }^{9) . S P M} の$ 派生化の進展に伴い，まず 用語やデータ形式に対する標準化ニーズが高まった。 21世 紀初頭においても SPM 用語は統一されて抢らず, 同一手法 に対して異なる名称が用いられる等のユーザーにとって不確 かさがあった。また，SPM装置製作企業ごとに，異なる データ形式を採用していたため, 異なる SPM 装置間のデー タ比較が困難であった．このような SPM の工業標準化の初 期に拈いては用語法を含むデータマネジメントの標準化が重 要である. 本解説では ISO/TC 201 を中心とした走査型プ ローブ顕微鏡データマネジメントの標準化のこれまでの展開 と今後の展望について紹介する. 


\section{SPM 標準化のロードマップ}

ISO におけるSPM の国際標準化に向けた取り組みが本格 的に開始された直後の2006年に Fujita らは SPM 国際標準 化 (Global Standardization of SPM)の工程表を提案した10). その後の ISO における展開を踏まえた SPM 国際標準化ロー ドマップをFig. 1 に示す. 当時においても現在に打いても 最優先で取り組むべき項目は SPM に用いられる用語の標準 化である．TC 201で表面化学分析に係る用語の定義の標準 化を担当する小委員会である SC 1 (terminology)において, 英国の Seah（National Physical Laboratory, NPL）をプロジ エクトリーダーとして規格化が 2004年から進められた。 2007年に SPM に関する用語が既存の用語に関する規格であ る ISO 18115 : 2001 (Vocabulary) に対する修正版として, ISO 18115：2001/Amd.2:2007が発行された。さらに, 2010年には表面化学分析に関する用語を二分冊化し，SPM 単独の用語の国際標準規格として ISO 18115-2：2010 (Terms used in scanning-probe microscopy) が発行され た ${ }^{11)}$. 略語, 手法の定義, 接触力学に関する用語の定義と 頭字語について記載されている. SPM は技術開発の進展が 速い計測法であり，数年の間に新しい計測モードやプローブ が実用化される，最新の技術革新を取り入れるため，既に成 立した ISO 18115-2：2010の改訂（amendment）が開始さ れている。我が国においても，産業進展とユーザー利便性を 高めるために, ISO 18115 に対応した SPM 用語に関する日 本工業規格（JIS）化が2013年から実施される.

SPM 用語の規格化を起点として，大きく分けて国際標準 化は二方向へ進展する. 第一の方向は, SPM のデータ管理 (data management) に関する標準化である。データ形式, データ処理法，データベースなどに関する標準化を目指すこ とにより，多元的な SPM データを共通的に処理する環境を 構築することを目指している.

もう一つの方向は, SPM 計測法の方法論 (methodology) や測定ガイドラインなど, 度量衡学的な計測 (metrology) に関する標準化である，測定システムの校正方法，ドリフト

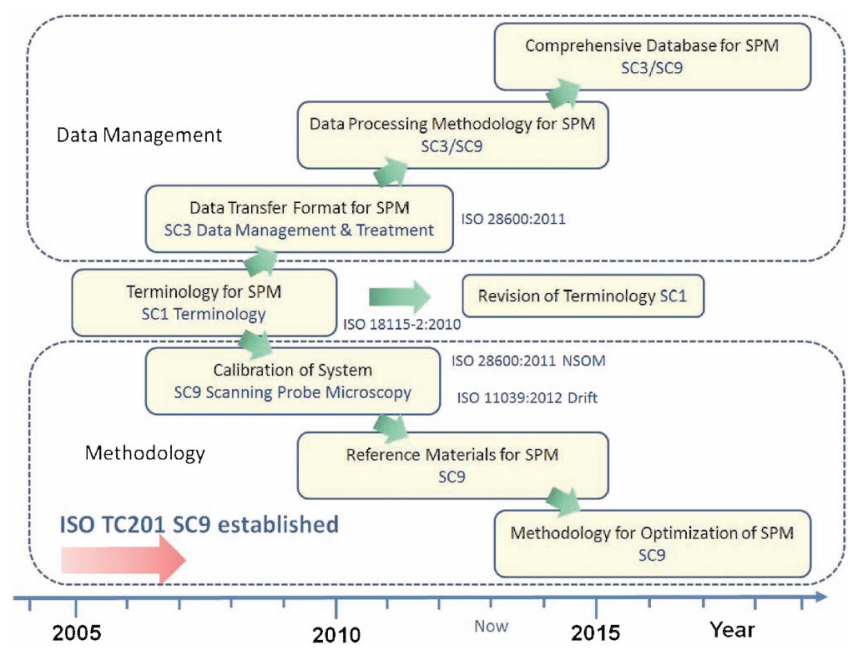

Fig. 1 Roadmap of global standardization for SPM in the scheme of ISO TC 201 for surface chemical analysis.
や探針形状効果などの測定方法，様々なアーティファクトの 補正方法，校正や補正に必要となる認証標準物質（Certified Reference Material, CRM) や標準物質 (Reference Materials, RM)，フィードバックシステムに打䛊差信号やド リフトによるアーティファクトを最小化するための最適化の 方法など，SPM 計測における信頼性向上と定量化に関する 事項である。

\section{3. データ管理の標準化プロセス}

表面化学分析に係るデータの管理と処理の標準化に関して は，TC 201では SC 3 (Data management and treatment) が所掌する。そのため，SPMのデータマネジメントに係る 提案は SC 3 で審議される. 提案された SPM のデータ管理 と処理に関する標準化のプロセスを Fig. 2 に示す10).

従来，SPM 装置を製作し，市場に提供する SPMメ一 カーならびに装置を自作する研究者等は独自の最適化に基づ くデータフォーマットを用いてきた．これらのデータフォー マットはバイナリー（binary）形式であり，その読取りには バイナリーデータを解読するための専門的な知識を要する. また，測定パラメータ等の情報を得ることはフォーマットの 詳細な情報が既知でなければ不可能である。そのため，異な るメーカーの装置間のデータには互換性がなく，SPM デー 夕の定量的な相互比較が困難であった．SPM データの相互 比較を可能にするためには，データ転送フォーマット（data transfer format）の標準化が重要である．既にオージェ電子 分光法や光電子分光法などの表面化学分析では異なる計測装 置間のデータを比較するためのデータ転送フォーマットが ISO 14976 : 1998 (Data transfer format）として制定され ており12)，日本工業規格（JIS K0141：2000） へ翻訳 JIS 化 されている13). 各装置の固有データ形式のファイルをデー タ転送フォーマットのファイルに変換することにより，多様 な装置から得られた SPM データを管理し，寸法校正や各種 の補正などのデータ処理を施すことができる。また，データ 転送フォーマットのみならずバイナリー形式のデータフォー マットを将来的に標準化する。これらにより，共通的なデー タ処理環境と連携した SPM データ管理環境，すなわち統合

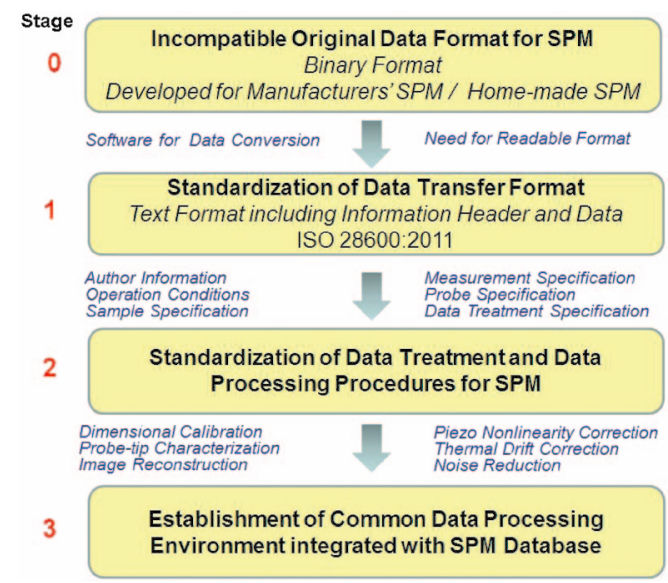

Fig. 2 Proposed standardization process of data management and treatment for SPM. 
データベースの構築が可能になる見通しである。

\section{SPM データ転送フォーマット}

ISO 14976の基本的なアーキテクチャーに立脚した SPM データ転送フォーマットの標準化に関する検討は，2004年 から TC 201 / SC 3 に設置された検討グループ（Study Group, SG）において開始された. SGでの標準化ニーズの サーベイ調査に基づき, 正式な新規作業項目提案（New Work Item Proposal, NWIP) は, 我が国の日本工業標準調 查会 (Japanese Industrial Standards Committee, JISC) が 2008年に行ったものである. ISO TC 201/SC 3 に抢いて は, 物質 ·材料研究機構 (National Institute for Materials Science, NIMS) の Fujita がプロジェクトリーダーとして規 格としての文書化を主導し，2011年に ISO 28600:2011 (Data transfer format for scanning-probe microscopy) とし て発行された ${ }^{14)}$.

SPM データ転送フォーマットは SG での検討当時から既 存の規格である ISO 14976に準じることが求められ，異な る計算機アーキテクチャーにおいても読取が容易なテキスト （text）形式とされた. Fig. 3 に示すように，128行の情報へ ッダー（information header）に続くデータブロックにより 構成される．情報へッダーには，測定者や測定日時，測定装 置などに関する一般的情報の他に, 走査条件, 測定環境, 探 針や試料, データ処理などに関する情報が含まれている. SPM データブロックには一般的な等間隔に測定されたイ メージデータがテキスト形式で収納される. $512 \times 512$ のイ メージデータで約 $3 \mathrm{MB}$ である. 一方, 不等間隔の SPM データや複数チャネル同時測定の場合の多元的測定データに も対応できる. 文字情報（text）のみのファイルであり，テ キストエディターによりファイルの作成, 編集, 保存を容易 に行うことができることが特長である. そのため，データの 交換性と統一されたデータ処理プログラム開発を容易にし, 定量性の向上に寄与するものと期待している.

また，ISO 28600 : 2011に準拠したデータ変換ソフトウエ アの開発が NIMS により進められている．Fig. 4 に示すよ うに, 国内外の SPM 装置メーカーのデータ形式に対応した 変換プログラムがホームページにて公開されている15). 本 プログラムでは各装置固有データファイルを読取り, ISO 28600に準拠したデータ転送フォーマット（.spm）へ変換す る機能と編集機能，ならびに同様のデータヘッダーを含むバ イナリー形式 (.spd) への変換機能を有する. また，傾き補 正やラインプロファイル測定などの基本的なデータ処理機能 を有している.

一方，データ変換に引き続くデータ管理に関するステージ では, Fig. 2 に示すように探針形状評価やイメージ補正など のデータ処理法の標準化を進めることになる ${ }^{16)}$. NIMS で は ISO 28600準拠の高度な SPM データ処理プログラムとし て，ドリフト速度や探針形状の測定ならびに補正機能を開発 中である．データ変換・データ処理環境と統合された SPM データベースの構築を目指して抢り，多様な SPM データに 容易にアクセスできる環境が提供される見通しである.
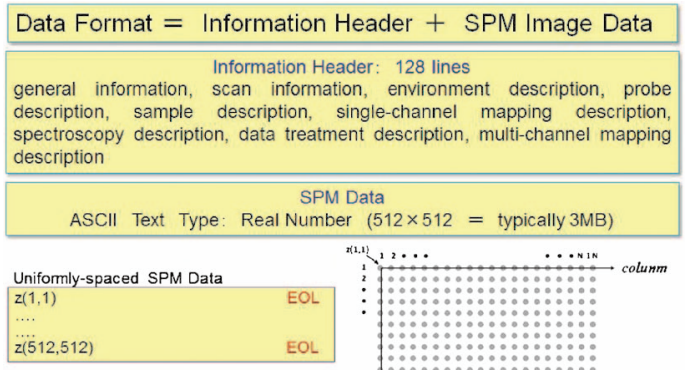

General SPM Data (single image) $x(1,1), y(1,1), z(1,1)$

$\dddot{x(512,512), y(512,512), z(512,512) \quad E O L}$

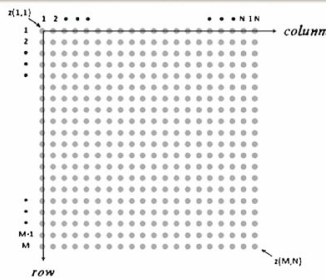

Fig. 3 Standard data transfer format for SPM based on ISO 28600. It consists of information header followed by SPM data expressed in text format.

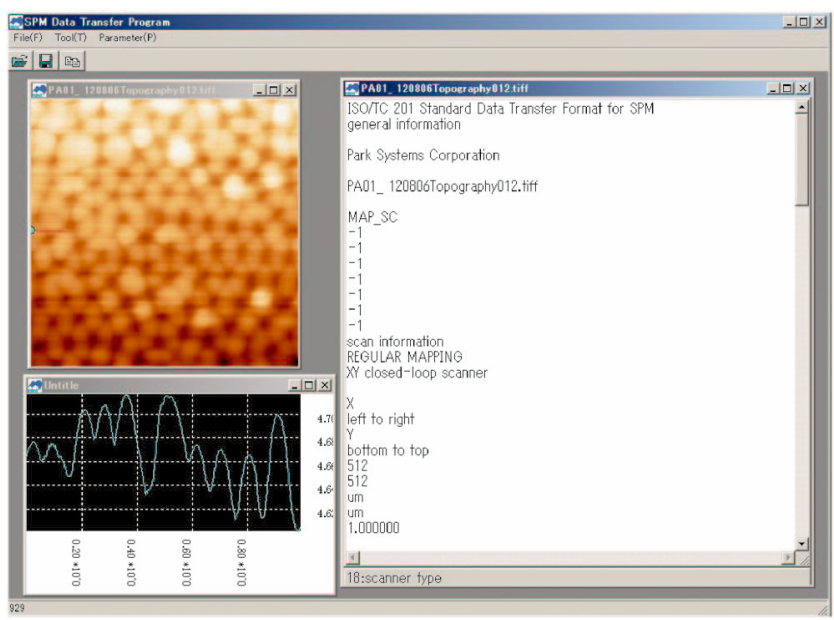

Fig. 4 NIMS open software for the SPM data conversion into the standard data transfer format based on ISO 28600.

\section{5. デー夕処理の標準化}

SPM データに対するデータ処理には傾き補正，ノイズ低 減, FFT処理などの画像データに関する基本的なプロセス が必要である.さらに, SPM 計測法に特有のアーティファ クトに対する補正のためのデータ処理が必要とされる．この ようなアーティファクトは定量的に計測することにより補正 が可能となる. 最近の市販 SPM においては位置センサーと closed-loop 方式の導入により，XYZ 軸走査に用いられるピ エゾスキャナーの非線形性（Piezo nonlinearity）に対する 実時間補正が可能である. 残された SPM トポグラフィー計 測において実形状を歪ませるアーティファクトとしては，ド リフト，探針形状効果，フィードバック制御系の応答特性が 存在する. 応答特性は, 走査条件の最適化により, 誤差信号 を許容レベル以下に最小化することができる，定量的な応答 特性の測定や補正法の確立は今後の課題である．ここでは定 量化の方法や標準化の方向が比較的明確であるドリフトと探 針形状効果の評価と補正に関するデータ処理について紹介す る.

\section{1 ドリフト速度の定量的な評価法}

ドリフトは試料と探針の相対位置が時間とともに変化する 
現象であり，一般に熱伝導度の違いや温度分布により生じる ものと考えられ, thermal drift とも呼ばれる．XYZ軸方向 のドリフト速度（drift rate）を定量的に計測することは， SPM 装置の安定性を評価する上で重要である。ドリフト速 度は三次元べクトルであり，単位時間当たりの各座標軸にお けるドリフト量が $\mathrm{X}, \mathrm{Y}, \mathrm{Z}$ 成分 $(\mathrm{nm} / \mathrm{s})$ である.

2012年に, 中国（国家標準化管理委員会, Standardization Administration of China, SAC) 提案の「ドリフト速度 の定義と測定法」に関する ISO 11039 ：2012（Definition and measurement methods of drift rates of SPMs) が発行さ れた ${ }^{17)}$. SAC は中国国家標準規格 (Guo jia Biao zhun, GB 規格）の制定と公布を行っている.

ISO 11039規格文書ではドリフト速度の測定法として, 画 像相関（image correlation）法 ${ }^{18)}$, 特徵的マーカー ( characteristic marker) 法 ${ }^{19)}$, 非周期グレーティング (non-periodic grating) 法20)が提示されている。これら三つ の方法では前者 2 つ実試料でドリフト速度を評価できる が，後者は認証標準物質 $(\mathrm{CRM})$ もしくは標準物質 (RM) が必要である.

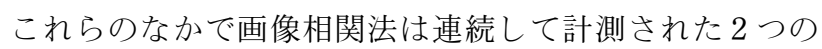
画像間の相互相関関数を求めることによりドリフト速度を定 量評価するものであり, SPM 像を補正するデータ処理法と して標準化の対象とすべき手法である. 参照像を $f(x, y)$ と し, 比較すべき対象となる像を $g(x, y)$ とすると, 両者の相 互相関関数 $C(u, v)$ は以下の式で計算される.

$C(u, v)$

$$
=\frac{\sum_{x} \sum_{y}\left[f(x, y)-f_{m}\right]\left[g(x+u, y+v)-g_{m}\right]}{\sqrt{\sum_{x} \sum_{y}\left[f(x, y)-f_{m}\right]^{2}} \sqrt{\sum_{x} \sum_{y}\left[g(x+u, y+v)-g_{m}\right]^{2}}}
$$

ここで $f_{m}, g_{m}$ は各々デジタルイメージ $f$ と $g$ 像平均值で ある、実際の画像相関法によるドリフト速度の評価プロセス を Fig. 5 に示す. AFM 像 1 と 2 は連続して計測されたナ ノ粒子のトポグラフィー像である. 両者の相互相関関数を計 算して画像化すると中心近傍に極大值ピークが観察される. この極大值ピーク位置の中心から変位が X, Y 方向のドリフ 卜距離（ピクセル換算）である. Fig. 5 の場合, 下向きの二 次元ドリフト速度ベクトルが得られる.Z方向のドリフト速 度は対応する領域の高さ変位の平均值の解析により得られる.

ドリフト速度の定量的評価により, 時間的に変化する画像 歪を補正することができる. NIMSでは画像相関法による ドリフト速度評価のためのオープンソフトウェアを開発中で ある。一方，実用的な観点からはドリフト速度による歪を同 時的に補正する手法の確立が求められる ${ }^{21)}$.

\section{2 探針形状効果の測定と補正}

ドリフト速度が無視できるほど小さく，かつ走査速度やフ ィードバックループゲイン等の走査条件が最適化されている 場合, SPM 表面卜ポグラフィー計測に抬いて本質的なアー ティファクトは, 有限サイズの探針先端形状から引き起こさ れる探針形状効果である.

SPM に㧍けるトポグラフィーイメージの測定は, モルフ オロジー演算（mathematical morphology）と呼ばれる画像 の集合演算に係る学問分野における膨張処理（dilation）に より表現できる ${ }^{22)}$. SPM 計測イメージ $z(x, y)$ は，真の表 面トポグラフィー $s(x, y)$ を探針形状 $t(x, y)$ により膨張 (dilate) されたものに相当する. 歪んだ SPM 像はモルフォ ロジー演算に㧍ける収縮処理 (erosion) により画像の再構 成 (reconstruction) をすることが可能である.これらのデー タ処理により, Fig. 6 に示すように, 真の表面トポグラフ ィーにより近い像 $r(x, y)$ を得ることができる.しかしなが ら, Erosion 処理はデコンボリューションと異なり，探針が 相互作用していない試料表面を復元することができないた め, 再生不可能な領域が必ず生じることに注意が必要である.

一方，トレンチ構造などのナノスケールでの既知形状を有 する標準物質の AFM トポグラフィー計測から探針先端形状 を抽出する試みがなされている23). 探針形状評価のため, ナノ構造加工技術により作製されたプローブキャラクタライ

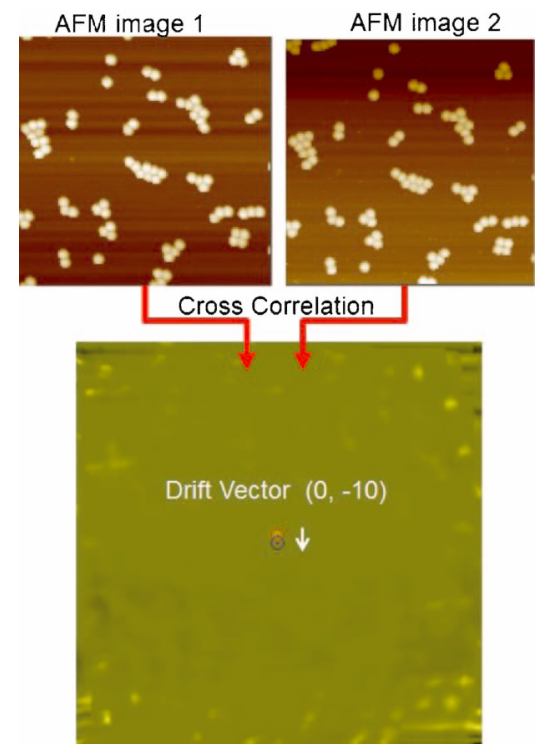

Fig. 5 Extraction of drift rate vector from sequentially measured data by image correlation method. The deviation of the maximum peak from the center of the cross correlation matrix is the drift distances in pixels between the two images.

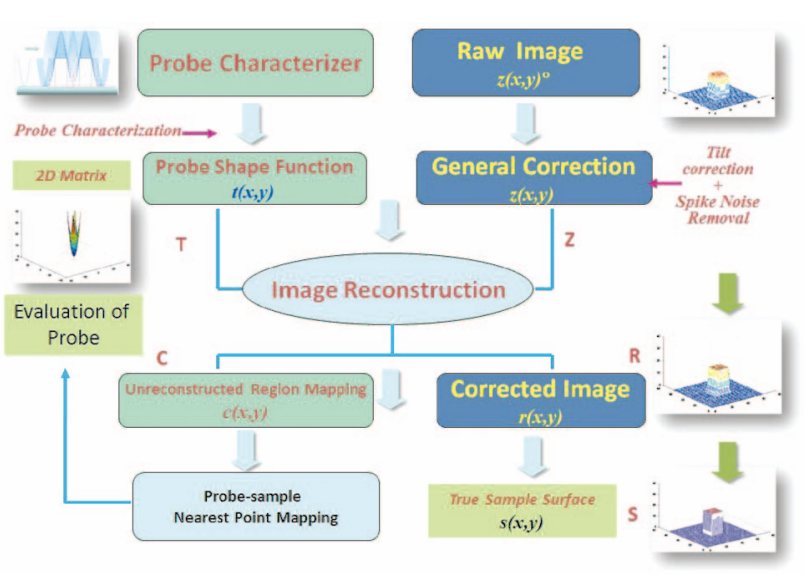

Fig. 6 Data processing procedures for the measurement of probe shape function (PSF) and image reconstruction. 
ザの開発が産業技術総合研究所 (National Institute of Advanced Industrial Science and Technology, AIST) の Itoh と Ichimura を中心として進められている.さらに，プローブ キャラクタライザ表面上を走査することにより，探針先端形 状をその場評価する方法の標準化（WD13095 Procedure for in situ characterization of AFM probes used for nanostructure measurement）が JISC からの提案として ISO 文書化が 進展している. 探針評価法と RM の標準化を進めることに より，探針先端形状を定量的に評価するための指標である探 針特性関数 (Probe Characteristic Function, PCF) や探針形 状関数 (Probe Shape Function, PSF)を得ることができる24).

PCF は, 曲率半径やコーン角度などの従来からの探針特性 量とともに探針先端の先鋭度を表す定量的指標となる. 探針 先端形状を三次元表示する PSF についてはデータフォーマ ットの標準化が望まれる. NIMS で開発中のオープンソフ トウェアでは Fig. 7 に示すようなへッダーと数值データか ら構成されるテキスト形式のフォーマット（.psf）を提唱し ている. 典型的なピクセルサイズ（例 $51 \times 51 ）$ は画像デー タのサイズ $($ 例 $512 \times 512)$ の $1 \%$ 程度であり, テキスト形 式が適している.

様々な方法で実測されたPSFを用いて実測された AFM 画像にデータ処理を施すことにより，より実像に近いトポグ ラフィー像を再構成することができる. 例えば, 真球形状と みなせる “標準球形ナノ粒子”（ポリスチレンナノ粒子）の 場合, Dilation 効果により水平方向に膨張されたトポグラフ ィ一像となるため, 真直径を実測 AFM 像から知ることがで きない. 実測されたPSF を用いた AFM 画像の再構成処理 の実例を Fig. 8 に示す. 再構成像では, 高さと釣り合った 合理的な直径を得ることができる.このように，ナノ物体の 形状と寸法を定量的かつ精密に評価する測長 (Critical Dimension, CD）計測を AFMにより実現するためには， PSF の測定と再構成処理が不可欠である. CD 計測に用いる べき高精度のPSF を抽出するためには〜 $1 \mathrm{~nm}$ スケールの寸 法精度のナノ構造を有する標準物質が必要とされる。

一方, ブラインド再構成（Blind Reconstruction, BR）法 は，精密な既知形状を有する標準物質のみならず，実試料の $\mathrm{AFM}$ トポグラフィー像から探針形状関数を抽出できる手法 である ${ }^{25)}$. BR 法から得られた PSF の妥当性評価, BR 法に 適した標準物質, 適正な画像処理プロトコルの整備が求めら れている。再現性のある像再構成プロセスに対しては, SPM ユーザーのニーズがあり, プレ標準化研究に基づいて 国際標準化を進めていく必要がある. 既に BR 法による定量 的な PSF の抽出と像補正に関するプレ標準化のため, VAMAS TWA2 での RRT が2012年から開始されている.

\section{6. まとめと展望}

SPM データ管理とデータ処理に係る国際標準化活動に関 して, ISO TC 201 における活動を中心に紹介した. SPM を 所掌するSC 9 はプロジェクト (Approved Work Item, AWI) を担当する作業部会（Working Group, WG）から構成され る. 2006年〜2007年にかけて多くの NWIP が各国からなさ れ, WG 1 (近接場顕微鏡) から WG 6 (SPM 電気的磁気的
Data Format for Probe Shape Function .psf

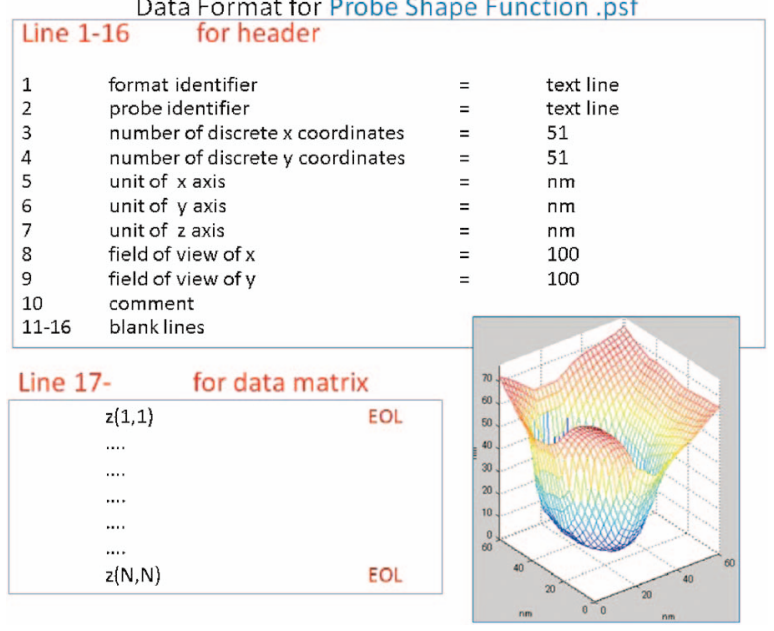

Fig. 7 Proposed data format for PSF and its typical example with 3-D representation.
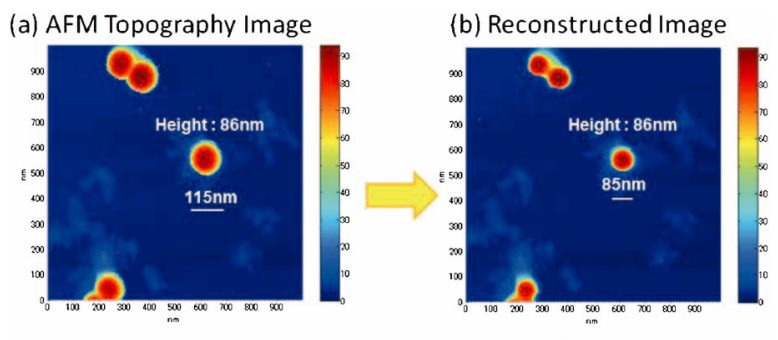

(c) SEM Image

Polystyrene Spherical Particles diameter $\sim 90 \mathrm{~nm}$

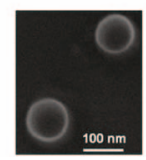

after reconstruction.

Fig. 8 Demonstration of image reconstruction using the measured PSF in the case of standard nanosphere particles dispersed on $\mathrm{Si}(001)$ wafer. AFM topography image (a), reconstructed image (b), and SEM image (c).

測定）まで設置された。 SC 9 以外でもSC 1 においては $\mathrm{SPM}$ 用語, SC 3 においては SPM のデータ管理と処理に関 する国際標準化作業が実施されている，既にSPM に関する 国際標準規格として 4 本の ISO 規格文書が成立しており, 重要度の高いSPM 用語に関しては翻訳 JIS 化を2013年に実 施する段階にある。

今後の SPM 標準化においてはポリマーやバイオマテリア ル等のソフトマテリアルに対応する SPM 計測法, 半導体等 のナノデバイスの電気的磁気的測定法の標準化が重要とな る. 現在, 日本側から NWIPを行う段階にあり, 有用性評 価のための国際RRTをVAMASスキームで実施してい る. 国際共同試験により集められたデータを共通的に解析す る上でも SPM データ管理の標準化は重要である.

SPM は今後も大きな進化の可能性を秘めて抢り，新規ナ ノ計測機能の開発が現在進行形である。新たな SPM 計測手 法が開発され, 研究開発に供されている. 一方, 広範な利用 拡大は定量化と標準化のニーズを高めて抢り, 国際標準化の 駆動力となっている.これまでの ISO TC 201を中心とした 活動の諸成果を基盤にして, 産業界やユーザーのニーズに対 
応し，SPM の普及と利用の拡大，さらに定量性や正確性を 向上させるような国際標準化が期待されている．産学官連携 協力の一環として，SPMを定量ナノスケール計測法へ進化 させる標準化活動に一層の協力を関係各位にお願いしたい.

\section{〔文献〕}

1) G. Binnig and H. Rohrer: Helv. Phys. Acta, 55 (1982) 726.

2) R. Young, J. Ward and F. Scire: Rev. Sci. Instrum., 43 (1972) 999.

3) G. Binnig, C. F. Quate and Ch. Gerber: Phys. Rev. Lett., 56 (1986) 930

4) H. X. Guo and D. Fujita: Rev. Sci. Instrum., 82 (2011) 123706.

5) D. Fujita and K. Sagisaka: Sci. Technol. Adv. Mater., 9 (2008) 013003.

6) T. Ohmura, A. Kurokawa, T. Homma, D. Fujita, K. Goto, M. Uemura, H. Tokutaka, K. Yoshihara, M. Kurahashi, S. Ichimura, C. Oshima, F. Soeda, Y. Fukuda, Y. Hashiguchi, K. Tanaka, M. Kudo, T. Hayashi, A. Tanaka, Y. Shiokawa, T. Sekine and R. Shimizu: Shinku, 31 (1988) 744.

7) ASTM E1813-96, "Standard Practice for Measuring and Reporting Probe Tip Shape in Scanning Probe Microscopy", (1996).

8) T. Kurosawa: J. Surf. Anal., 11 (2004) 178.

9) S. Ichimura and H. Nonaka: Nanotechnology Standards (Springer, New York, 2011) p. 132.

10) D. Fujita, H. Itoh, S. Ichimura and T. Kurosawa: Nanotechnology, 18 (2007) 084002.
11) ISO 18115-2: 2010 Surface chemical analysis-Vocabulary Part 2: Terms used in scanning-probe microscopy (2010).

12) ISO $14976: 1998$ Surface chemical analysis - Data transfer format (1998).

13) JIS K0141: 2000 (ISO $14976: 1998)$ (2000).

14) ISO $28600: 2011$ Surface chemical analysis - Data transfer format for scanning-probe microscopy (2011).

15) http:// www.nims.go.jp/research / organization/akt-database. html

16) D. Fujita, K. Onishi and M. Xu: J. Phys. Conf. Ser., 159 (2009) 012002.

17) ISO 11039 : 2012 Surface chemical analysis-Scanning-probe microscopy - Measurement of drift rate (2012).

18) W. -H. Huang, W. -W. Wang, A. -D. Xia, N. Jin and Z. -Q. Hu: J. Vac. Sci. Technol. B, 18 (2000) 2027.

19) C. A. Clifford and M. P. Seah: Meas. Sci. Technol., 20 (2009) 095103.

20) Y. -H. Chen and W. -H. Huang: Rev. Sci. Instrum., 78 (2007) 073701.

21) M. Abe, Y. Sugimoto, T. Namikawa, K. Morita, N. Oyabu and S. Morita: Appl. Phys. Lett., 90 (2007) 203103.

22) M. Xu, D. Fujita and K. Onishi: Rev. Sci. Instrum., 80 (2009) 043703.

23) C. -M. Wang, H. Itoh, J. -L. Sun, J. Hu, D. -H. Shen and S. Ichimura: J. Nanosci. Nanotechnol., 9 (2009) 803.

24) K. Onishi and D. Fujita: Anal. Sci., 27 (2011) 157.

25) J. S. Villarrubia: J. Res. Natl. Stand. Technol., 102 (1997) 425. 